\title{
Front Matter: Volume 10909
}

, "Front Matter: Volume 10909," Proc. SPIE 10909, Laser 3D Manufacturing VI, 1090901 (22 May 2019); doi: 10.1117/12.2531481

SPIE. Event: SPIE LASE, 2019, San Francisco, California, United States 


\section{PROCEEDINGS OF SPIE}

\section{Laser 3D Manufacturing VI}

Bo Gu

Henry Helvajian

Hongqiang Chen

Editors

5-7 February 2019

San Francisco, California, United States

Sponsored and Published by

SPIE 
The papers in this volume were part of the technical conference cited on the cover and title page. Papers were selected and subject to review by the editors and conference program committee. Some conference presentations may not be available for publication. Additional papers and presentation recordings may be available online in the SPIE Digital Library at SPIEDigitallibrary.org.

The papers reflect the work and thoughts of the authors and are published herein as submitted. The publisher is not responsible for the validity of the information or for any outcomes resulting from reliance thereon.

Please use the following format to cite material from these proceedings:

Author(s), "Title of Paper," in Laser 3D Manufacturing VI, edited by Bo Gu, Henry Helvajian, Hongqiang Chen, Proceedings of SPIE Vol. 10909 (SPIE, Bellingham, WA, 2019) Seven-digit Article CID Number.

ISSN: 0277-786X

ISSN: 1996-756X (electronic)

ISBN: 9781510624603

ISBN: 9781510624610 (electronic)

Published by

SPIE

P.O. Box 10, Bellingham, Washington 98227-0010 USA

Telephone +1 3606763290 (Pacific Time) · Fax +1360 6471445

SPIE.org

Copyright @ 2019, Society of Photo-Optical Instrumentation Engineers.

Copying of material in this book for internal or personal use, or for the internal or personal use of specific clients, beyond the fair use provisions granted by the U.S. Copyright Law is authorized by SPIE subject to payment of copying fees. The Transactional Reporting Service base fee for this volume is $\$ 18.00$ per article (or portion thereof), which should be paid directly to the Copyright Clearance Center (CCC), 222 Rosewood Drive, Danvers, MA 01923. Payment may also be made electronically through CCC Online at copyright.com. Other copying for republication, resale, advertising or promotion, or any form of systematic or multiple reproduction of any material in this book is prohibited except with permission in writing from the publisher. The CCC fee code is 0277$786 \times / 19 / \$ 18.00$.

Printed in the United States of America by Curran Associates, Inc., under license from SPIE.

Publication of record for individual papers is online in the SPIE Digital Library.

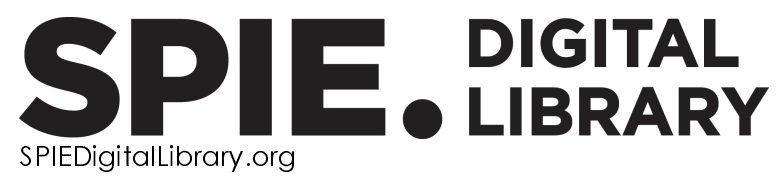

Paper Numbering: Proceedings of SPIE follow an e-First publication model. A unique citation identifier (CID) number is assigned to each article at the time of publication. Utilization of CIDs allows articles to be fully citable as soon as they are published online, and connects the same identifier to all online and print versions of the publication. SPIE uses a seven-digit CID article numbering system structured as follows:

- The first five digits correspond to the SPIE volume number.

- The last two digits indicate publication order within the volume using a Base 36 numbering system employing both numerals and letters. These two-number sets start with $00,01,02,03,04$, 05, 06, 07, 08, 09, 0A, OB ... 0Z, followed by 10-1Z, 20-2Z, etc. The CID Number appears on each page of the manuscript. 


\title{
Contents
}

\author{
vii Authors \\ ix Conference Committee
}

NEW TECHNOLOGIES IN DLW: JOINT SESSION WITH 10909 AND 10930

1090903 Axial resolution improvement in multiphoton polymerization by 4Pi excitation [10909-2]

POWDER-BED SLM METAL PRINTING

1090907 A deep dive into metal 3D printing (Invited Paper) [10909-6]

$1090908 \quad$ Influence of multi-spot exposure of powder bed on melt pool stability in selective laser melting [10909-7]

1090909 Area melting with multi-laser arrays to increase build rate for metal powder bed fusion additive manufacturing [10909-8]

10909 OA Concepts for integrating laser polishing into an additive manufacturing system [10909-9]

NEW TECHNOLOGY FOR COPPER PRINTING

10909 OC Blues skies for copper cladding with 450nm (Invited Paper) [10909-11]

10909 OD Additive manufacturing of pure copper using ultrashort laser pulses [10909-12]

\section{MULTI-MATERIALS PRINTING}

10909 OG Individual material and process development in laser based additive manufacturing [10909-15]

$10909 \mathrm{OH} \quad$ Phenomena in multi-material fabrication using laser metal deposition (Invited Paper) [10909-16] 


\section{LASER CLADDING AND HOT WIRE PRINTING}

10909 0J Wire-based direct metal deposition with Ti6Al4V (Invited Paper) [10909-17]

10909 OL Additive manufacturing by wire based laser metal deposition (Invited Paper) [10909-19]

PROCESS MONITORING AND CONTROL

10909 OM Influence of energy input on spatter generation of 316L stainless steel fabrication by SLM in vacuum (Invited Paper) [10909-20]

$1090900 \quad$ Layer-wise powder deposition defect detection in additive manufacturing [10909-22]

NOVEL MATERIAL AND DEVICE PRINTING

10909 OP Inkjet printing enabled rapid prototyping and model verification processes (Invited Paper) [10909-24]

$109090 Q \quad$ Direct write of photonics using a filament-fed laser-heated process [10909-25]

MICROPRINTING AND FORWARD TRANSFER

10909 OT Femtosecond laser induced damage threshold (LIDT) of 3D nanolithography made micro- and nano-optical elements [10909-28]

\section{D METROLOGY AND INSPECTION}

10909 OV Time-based offline track planning of robot guided laser applications for complex 3D freeform surfaces (Invited Paper) [10909-30]

10909 OW Irradiation angle dependence and polarization dependence in 3D geometry measurement using AMCW LiDAR [10909-31]

iv 
POSTER SESSION

10909 OY Pure copper layer formation on copper based alloy substrate with $100 \mathrm{~W}$ class blue diode laser [10909-33]

$109090 Z$ Effect of input energy on densification for pure copper fabricated by SLM with blue diode laser [10909-34]

1090916 Precise and large-dynamic-range surface profilometry using time-of-flight detection of femtosecond optical pulses [10909-41] 
Proc. of SPIE Vol. 10909 1090901-6

Downloaded From: https://www.spiedigitallibrary.org/conference-proceedings-of-spie on 26 Apr 2023 Terms of Use: https://www.spiedigitallibrary.org/terms-of-use 


\section{Authors}

Numbers in the index correspond to the last two digits of the seven-digit citation identifier (CID) article numbering system used in Proceedings of SPIE. The first five digits reflect the volume number. Base 36 numbering is employed for the last two digits and indicates the order of articles within the volume. Numbers start with 00, 01, 02, 03, 04, 05, 06, 07, 08, 09, OA, OB...0Z, followed by 10-12, 20-2Z, etc.

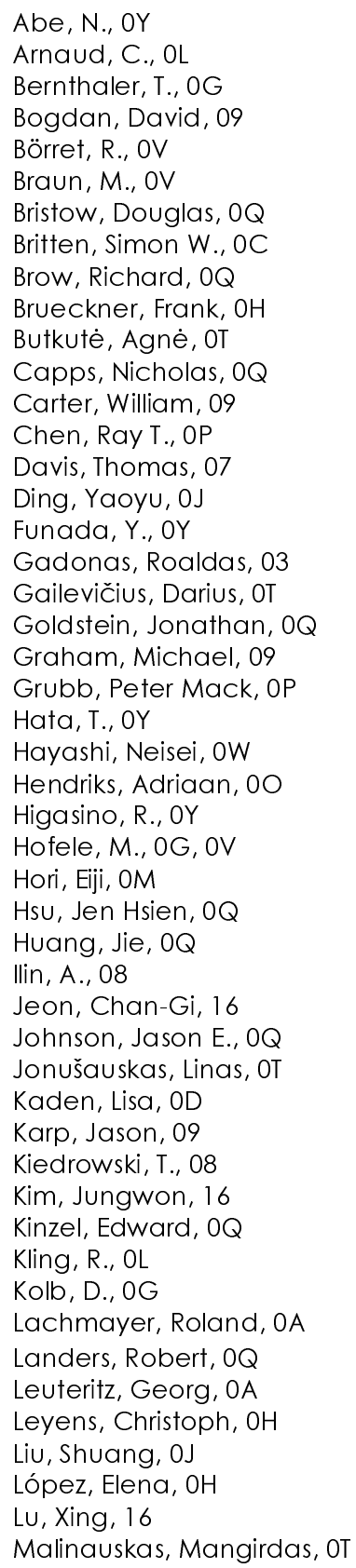

Marquardt, Franz, $\mathrm{OH}$

Masuno, S., $\mathrm{OZ}$

Matthäus, Gabor, OD

McCarthy, Brian, 09

Mizeikis, Vygantas, OT

Moroko, M., 00

Müller, Michael, $\mathrm{OH}$

$\mathrm{Na}$, Yongjin, 16

Naidoo, Darryl, 00

Ngobeni, Chris, 00

Nolte, Stefan, OD

Ocylok, Sörn, OC

Ostroverkhov, Victor, 09

Ploshikhin, V., 08

Pohl, M., OV

Purlys, Vytautas, 03

Ramm, Roland, OD

Ramokolo, R., $0 \mathrm{O}$

Riede, Mirko, $\mathrm{OH}$

Riegel, H., OG, OV

Ruck, S., OG, OV

Sato, Yuji, OM, OY, OZ

Schab, Johannes C., $\mathrm{OH}$

Schanz, J., OV

Schneider, G., OG

Schubert, T., OG

Schurr, J., OG

Seidel, André, $\mathrm{OH}$

Set, Sze Yun, OW

Seyfarth, Brian, OD

Shi, Kebin, 16

Shibata, T., OZ

Slodczyk, M., 08

Srisawadi, Sasitorn, OM

Subbaraman, Harish, OP

Tanprayoon, Dhritti, OM

Tičkūnas, Titas, 03

Tsukamoto, Masahiro, OM, OY, OZ

Ullsperger, Tobias, OD

Valentin, M., OL

Yamashita, Shinji, OW

Zhang, Chao, oW

Zhu, Chen, $0 Q$ 
Proc. of SPIE Vol. 10909 1090901-8

Downloaded From: https://www.spiedigitallibrary.org/conference-proceedings-of-spie on 26 Apr 2023 Terms of Use: https://www.spiedigitallibrary.org/terms-of-use 


\section{Conference Committee}

Symposium Chairs

Beat Neuenschwander, Berner Fachhochschule Technik und Informatik (Switzerland)

Xianfan Xu, Purdue University (United States)

Symposium Co-chairs

Koji Sugioka, RIKEN Center for Advanced Photonics (Japan)

Reinhart Poprawe, Fraunhofer-Institut für Lasertechnik (Germany)

Program Track Chairs

Bo Gu, Bos Photonics (United States)

Stefan Kaierle, Laser Zentrum Hannover e.V. (Germany)

Conference Chairs

Bo Gu, Bos Photonics (United States)

Henry Helvajian, The Aerospace Corporation (United States)

Conference CoChair

Hongqiang Chen, GE Global Research (United States)

Conference Program Committee

Corey M. Dunsky, Aeos Consulting, Inc. (United States)

John T. Fourkas, University of Maryland, College Park (United States)

Youping Gao, Aerojet Rocketdyne (United States)

Craig Goldberg, Newport Corporation (United States)

Andreas Heinrich, Hochschule Aalen (Germany)

Weidong Huang, Northwestern Polytechnical University (China)

Edward C. Kinzel, Missouri University of Science and Technology (United States)

Jian Liu, PolarOnyx, Inc. (United States)

Alberto Piqué, U.S. Naval Research Laboratory (United States)

Yuji Sano, ImPACT (Japan)

Michael Thiel, Nanoscribe GmbH (Germany)

Paul S. Unwin, Stanmore Implants (United Kingdom)

Augustine M. Urbas, Air Force Research Laboratory (United States)

Martin Wegener, Karlsruher Institut für Technologie (Germany) 


\section{Session Chairs}

1 New Technologies in DLW: Joint Session with 10909 and 10930

Bo Gu, Bos Photonics (United States)

2 Novel Materials for DLW: Joint Session with 10909 and 10930

Harald Giessen, Universität Stuttgart (Germany)

3 Powder-bed SLM Metal Printing

Henry Helvajian, The Aerospace Corporation (United States)

4 New Technology for Copper Printing

Hongqiang Chen, GE Global Research (United States)

5 Multi-Materials Printing

Henry Helvajian, The Aerospace Corporation (United States)

$6 \quad$ Laser Cladding and Hot Wire Printing

Henry Peng, Institute of Applied Research on Intelligent Science \& Technology (China)

7 Process Monitoring and Control

Augustine M. Urbas, Air Force Research Laboratory (United States)

8 Novel Material and Device Printing

Hongqiang Chen, GE Global Research (United States)

9 Microprinting and Forward Transfer

Hongqiang Chen, GE Global Research (United States)

10 3D Metrology and Inspection

Corey M. Dunsky, Aeos Consulting, Inc. (United States) 